\title{
Political Scientists and Assisting Democracy: Too Tenuous Links
}

\author{
Kevin F. F. Quigley, The Asia Society
}

E fforts to promote or assist democracy and strengthen civil society are soaring in popularity in the postCold War world.' Motivated by the recent democratic revolutions in Eastern Europe and the easing of authoritarian regimes in Asia, Africa, and Latin America, there are now a plethora of public and private international actors involved in these efforts. In some way, most multilateral organizations, regional development banks, and major bilateral assistance programs, as well as literally thousands of non-governmental organizations (NGOs), are involved in democracy assistance efforts, even if these are not always explicitly labeled as such. Democracy assistance in the 1990s is achieving the same prominence that development assistance had in the 1960s. Yet, political scientists have made surprisingly scant contributions in this burgeoning field. Basic questions remain unanswered regarding the most effective strategies and techniques of democracy assistance, and political scientists could play an important role in answering them.

Lawyers, journalists, party activists, public administration, and development specialists, as well as accountants and consultants, have played a large role in democracy assistance efforts. U.S. lawyers have been involved through a variety of rule-of-law-related programs administered by the American Bar Association and other organizations, although these lawyers often lack familiarity with non-American systems of jurisprudence. These efforts are important for establishing the legal framework for democracy and have been helpful in many contexts in the constitution-making process. Lawyers also have been helpful in solidifying the legal basis for NGOs. Journalists have been involved in training a new cohort of independent journalists or establishing independent media centers, although in many cases the journalists know little about local politics and political culture and consequently espouse banal arguments like "you can't trust government." Party activists from the National Democratic Institute and the International Republican Institute have been involved in partybuilding in numerous transitioning societies, especially through the transfer of campaign technology. Public administration officials have been engaged in a variety of training programs, often designed to enhance the efficiency and responsiveness of government. Examples of these include programs administered by the Institute for Public Administration and the International City Managers Association. These public administration programs appear to have some impact, especially on the local level or where there is targeted technical assistance to address a particular problem. Following the end of the Cold War, development specialists have been attracted to democracy assistance as resources were reallocated away from development programs. Accountants and consultants have also been involved, since most internationally-funded programs impose high reporting standards and have relatively substantial resources. By contrast, political scientists engaged in democracy assistance efforts tend to have specific regional expertise, such as on Central Asia or the Balkans, and tend to be modestly involved.

Since President Reagan's June 1982 speech to the British Parliament, in which he made an explicit commitment to assisting democracy overseas, the United States has been the leading advocate for democracy assistance. During both the Bush and Clinton Administrations, this commitment has been one of the key tenets of U.S. foreign policy. It is not especially surprising that the United States and other industrialized democracies such as Denmark, Germany, Great Britain, the Netherlands, Norway, and Sweden underwrite democracy assistance efforts. It is remarkable, however, that coun- tries where democratic traditions are not as strong-such a Barbados, Chile, Costa Rica, India, Portugal, and South Africa-are also beginning to support similar efforts.

The recent proliferation of democracy assistance raises questions regarding how the field of political science relates to ongoing efforts to assist democracy. These questions fall into three broad categories: theoretical, practical, and pedagogic. ${ }^{2}$

\section{Theory and Democracy Assistance}

From a democracy assistance perspective, perhaps the greatest challenge for political theory is to develop insights that can readily be applied to programs designed to assist democracy. Although there is a rich literature on democratization, it provides little practical advice for those involved in democracy assistance efforts. While Robert Dahl, Samuel Huntington, Seymour Martin Lipset, Guillermo O'Donnell, and a host of other scholars have identified many of the preconditions for democratic regimes and the factors that make their ultimate success more likely, this literature does not offer practitioners the hoped-for blueprint for successful programs. Perhaps this is asking too much, but practitioners who look to political science for a grand theory explaining how democracies are constructed come away disappointed. The literature suggests the rather common-sense need to be modest about expectations and assume that lengthy time periods are required.

A related conundrum is that political scientists generally do not offer practitioners needed conceptual clarity about basic terms such as civil society and democracy; nor do they provide a clear understanding of the links between civil society and democracy or procedural and substantive democracy-to mention two critical sets of linkages. Although key concepts such as civil society and democracy have enjoyed near global 
use, there are no commonly agreed upon definitions for these basic concepts. The first lady of the United States, a journalist from South Africa, and the president of Krygyzstan may all use the term "democracy" with very different meanings. The term "democracy" is highly normative, as criticism by former Prime (now Senior) Minister Lee Kwan Yew of Singapore makes clear. This lack of conceptual clarity is further complicated by the fact that, for many politicians and practitioners, the movement toward more democratic political systems is perceived as identical to the movement toward more market-oriented economic systems. Political scientists generally understand that this may be true in some cases, but is not always so. If political scientists effectively conveyed this understanding to practitioners, much of the discussion about the links between market building and democracy assistance would not be so facile.

The relationship between civil society and democracy is also much more complicated than most practitioners assume. Many programs aiming to assist democracy are based on the dubious premise that strengthening civil society ipso facto bolsters democracy. Similarly, there is a common confusion between building the capacity of NGOs and strengthening civil society. Many programs are designed without sufficiently realizing that there are aspects of civil society and characteristics of certain NGOs that may impede democratic development. For example, a program designed to strengthen business associations as a component of efforts to reduce the state's monopoly over economic information may inadvertently lead to the development of a powerful lobby that places its particular interests above the public good. Given that practitioners often conflate civil society and democracy, there is clearly more work that can be done to elucidate the links among NGOs, civil society, and democracy.

Although this lack of conceptual clarity affects multiple aspects of democracy assistance, it is perhaps most evident when it leads to a blurring of the distinctions between procedural and substantive democracy. Among political scientists, the con- ventional wisdom recognizes the differences between the two: democratic form cannot be construed as democratic substance. There is, unfortunately, no convincing theorylet alone a viable road map-on how procedural democracy can be made more substantive. In addition, the pressure to produce discernible results placed upon democracy assistance practitioners by impatient legislatures results in further blurring of this distinction. Thus, the ability of a country, such as Bulgaria or Mongolia, to hold free and fair elections is often interpreted as a "democratic success," and used as a justification for committing additional resources.

Given this emphasis on results, it is understandable that the preponderance of democracy assistance programs have focused on procedural democracy. These include programs, such as those administered by the National Endowment for Democracy and the International Foundation for Electoral Systems, that assist electoral commissions, provide election observers, and train local leaders in techniques for monitoring elections. ${ }^{3}$ Many of these programs are developed upon the prevailing view that regular, open, competitive elections are the essential ingredient for the establishment and consolidation of democracy. These programs have produced impressive-if limited-results, assisting free elections at critical moments in diverse locales such as Haiti, Nicaragua, the Philippines, and Poland. Although there are perhaps political justifications for this emphasis on electoral processes-in that results are easily and quickly discernible-this view regarding the relative importance of procedural democracy needs to be more rigorously examined. Political scientists can play a very helpful role in this regard.

Political scientists can also help elucidate the connections between procedural and substantive democracy in other ways. For example, in Slovakia, which has received a relatively large amount of democracy assistance from the international community since it was established on January 1, 1993, there is a wide chasm between procedural and substantive democracy. Since 1993, Slovakia has had two rounds of free and fair national elections, which have been certified as such by international observers. Its legislature, partially as a result of international assistance, is more effective and transparent. Sessions of Parliament are televised, and votes are publicly recorded-all in sharp contrast with the opaque patterns of the recent past.

Nevertheless, Slovakia is a society with relatively little space for free expression and independent action, and political scientists would likely view it as having little substantive democracy. Civil society is perceived by government as oppositional, and independent voices in Slovak society are subject to persecution, whether such voices come from the media, educators, or the NGO sector. Slovakia has proven quite adept at holding elections. It has proven considerably less capable of developing substantive democracy. By rigorously examining specific cases like Slovakia, political scientists could usefully enhance our understanding of the nature of the links between procedural and substantive democracy. If these studies were conducted with an eye toward practical results, they might very well elucidate the most effective strategies for moving from the former to the latter.

\section{Improving Practice}

The theoretical question regarding the nature of the links between procedural and substantive democracy has important practical implications. Understanding this relationship would aid in the development of strategies and the creation of programs that are effective in helping consolidate democracies, moving from procedural to more substantive forms of democracy.

What are the relative merits of different approaches to assisting democracy? Should the international community place its primary emphasis on supporting democratic processes such as elections and free expression, or should there be greater attention devoted to developing democratic institutions such as responsive legislatures, independent judiciaries, and free presses? Aside from these more formal institutions, what is the relative importance for 
democratic consolidation of informal citizen-based organizations, such as NGOs, or programs designed to strengthen the rule of law? What impact, if any, do democracy assistance programs have on inculcating values essential to democratic practices, values such as tolerance, trust, and accountability?

Answers to these questions are complex, but political scientists are better positioned than any one else to answer them. In fact, one difficulty in designing better programs is the relative lack of clarity in what these programs aim to accomplish. In seeking answers to these questions, political scientists can help inject needed objectivity regarding the accomplishments of democracy assistance programs. In all too many circumstances, both public and private funders overpromise program outcomes, leading to expectations that cannot be met. Funders often describe their programs as democracy builders. Although it is true that programs which train teachers in new civic education curricula, or training courses for members of an independent judiciary, can be perceived as helping build democracy, this is building the democratic edifice one brick at a time. Laying a few bricks should not be construed as laying a foundation or building a wall. These programs do not generally provide sufficient resourcestime, money, or talent-to accomplish the goals that program designers set. Regional specialists, who were highly attuned to local circumstances and political culture, could provide invaluable advice regarding which bricks should be placed where and when.

This disparity between program goals and available resources leads to considerable frustration, as well as difficulty in evaluating what democracy assistance programs have actually accomplished. One training course cannot credibly claim to build democracy. It is relatively easy to develop quantitative measures regarding how many participants are involved in these training programs, or how many independent media centers or think tanks have been established. Unfortunately, the more interesting and important questions are not easily answered in quantita- tive terms. The most basic of these questions concern the quality of these training programs and the relative importance of an independent media center. Slightly more complex, and perhaps more important, are the questions of how and in what ways these training programs or new institutions have helped build democracy. These are difficult questions to answer. At this point, these questions are just beginning to be asked. Again, political scientists are well positioned to help answer them.

If democracy is essentially about providing a growing number of citizens with input into decisions on issues that affect them, the questions regarding how to improve the practice of democracy assistance must be answered in large part by the participants in these programs and their fellow citizens. All too often, questions regarding the impact of democracy assistance efforts are asked and answered by citizens of the donor countries. Regional specialists who are grounded in local languages and who possess an understanding of local political culture and historical developments, can shed important light on these issues.

Political scientists who are regional specialists can also help offset a common design flaw of many democracy assistance programs-the tendency for there to be "one-sizefits-all" (Carothers 1996). Whether it is the approach of the European Union, the German political foundations, or USAID, there has generally been insufficient attention to local circumstances. Programs designed for the Czech Republic, for instance, are replicated in Romania and Kazakhstan without much modification. Political scientists who are knowledgeable about specific countries could provide valuable assistance in improving the design of these programs, especially if they have worked closely with the citizens who will bear the ultimate responsibility for ensuring the effectiveness of democracy assistance efforts.

\section{Connecting to the Classroom}

The Third Wave of democratization that washed over much of the world at the end of the 1980s and the beginning of the 1990 s resulted in considerable enthusiasm. Although much of this initial enthusiasm was tempered by the challenges of consolidating newly democratic regimes, this enthusiasm carried into the classroom. Curricula were changed to reflect new global circumstances; syllabi were modified; a variety of new courses on NGOs, civil society, democracy, and related topics were introduced. Examining the experience of democracy assistance can help teachers address the challenge of bringing these exciting new developments into the classroom. In fact, the fledgling field of democracy assistance provides teachers a very practical way of exploring two of the most interesting questions in political science: 1) how do governments become more responsive to their citizens? and 2) what role do external actors play in this process?

In the past few years, a variety of descriptive materials on the democratization process has appeared. Notable among these is the work by Larry Diamond, Juan J. Linz, and Seymour Martin Lipset (1989). These provide a highly useful supplement to some of the more theoretical literature on democratization. Yet, despite its growing importance, there is scant empirically-based material on democracy assistance efforts. The current literature tends to be highly descriptive and involves a relatively small numbers of cases, such as Romania or Central Europe or Central America. The democracy assistance literature also tends to focus on one kind of funder, whether public or private, European or North American (Carothers 1996; Quigley 1997). In addition to complicating the process of generalization and theory-building, such a narrow focus misses the rich range of actors involved in democracy assistance. The plurality of actors involved in assisting democracy may be one of its most important strengths-a proposition that political scientists could test. ${ }^{4}$

To offset this gap, public and private funding agencies together with a small community of researchers are developing a series of empirically-based studies. For example, in 1994, USAID conducted a study of Bangladesh, Chile, El Salvador, Ke- 
nya, and Thailand in which the agency examined its contributions to civil society and democratization. Case studies related to the recent intensive engagement in Eastern Europe are also being developed. Examples include a study of a Hungarian NGO working with the Roma or gypsies, which is available from the Institute for the Study of Diplomacy at Georgetown University. Another is a study of efforts to reform the police in the Czech Republic, available from the case study program at the John F. Kennedy School of Government at Harvard University. Aside from these, the World Bank has developed a number of cases studies on this topic, available at http://www.worldbank.org/html/edi/ cases/caseindex.html. In addition, the World Bank's NGO Office is considering publishing a number of case studies involving interactions between it and civil society in different contexts. These materials can be readily adapted for classroom use in simulations and other interactive learning modes, especially in graduate schools and professional schools of international affairs.

Greater involvement of political scientists in generating empirical studies on democracy assistance will potentially introduce a wealth of new, highly relevant material into the classroom. Examining the development of democracy and the role outsiders play in that development can provide a potentially invaluable civic lesson, outlining the skills and attitudes required of the citizens of an enduring democracy.

\section{Strengthening Links}

The recent record of democracy assistance efforts-whether in Africa, Asia, Eastern Europe, or Latin America-shows that public and private actors are paying increasing attention, and devoting greater resources, to these efforts. This trend, despite pressure on the funding sources, is likely to continue. Up to this point, political scientists have had surprisingly tenuous links with the burgeoning field of democracy assistance despite the fact that they have considerable knowledge about democratization. In fact, political scientists have played a modest role relative to other professions, especially lawyers and journalists.

Without denigrating the contributions of lawyers and journalists, there are a number of important ways to strengthen the links between political science and democracy assistance. Political scientists could help provide more shared definitions of basic concepts, such as civil society and democracy, and elucidate the links between procedural and substantive democracy. In addition, they could generate new theoretical insights on a range of issues, insights that could enhance the quality and effectiveness of democracy assistance programs. In particular, area expertise regarding the particular context for democracy assistance efforts is much needed since these programs are often designed with a kind of "one-size-fits-all" approach. Political scientists can also help answer basic questions about the impact of democracy assistance efforts. Although empirical studies are becoming available, there are a number of opportunities for political scientists to generate teaching materials that can engage students in confronting the challenges associated with assisting democracy whether at home or abroad.

\section{Notes}

1. I prefer the term "assisting democracy" over the somewhat more commonly used term "promoting democracy," which some practitioners inappropriately consider synonymous with "promoting civil society." "Assisting democracy" more clearly places the impetus for democratic development where it belongs - on the countries attempting to develop democracy-rather than highlighting the role played by the external actor.

2. There is also a fourth question that is essentially political - why should we spend resources to promote or assist democracy abroad when there are dwindling resources to address problems at home? For initial answers to this question see Diamond (1995, $1-8)$.

3. Organizations sponsoring these programs include German political foundations (such as, Konrad Adenauer, Friedrich Ebert, Friedrich Naumann, and Hanns Seidel Stiftungen), the National Endowment for Democracy (including its related agencies-the Center for International Private Enterprise, the Free Trade Union Institute, the National Democratic Institute, and the International Republican Institute), the International Foundation for Electoral Systems, and the recently established Institute for Democracy and Electoral Assistance in Sweden.

4. This insight grew out of a series of workshops examining the record of democracy assistance in Eastern Europe. Contrary to the author's assumption, the Eastern European participants did not criticize the overall lack of coordination in democracy assistance. Instead, they suggested that, after 40 or 70 years of being coordinated from Moscow, this lack of coordination was an asset (see Quigley 1996).

\section{References}

Carothers, Thomas. 1996. Assessing Democracy Assistance: The Case of Romania. Washington, DC: Carnegie Endowment for International Peace.

Dahl, Robert. 1971. Polyarchy: Participation and Opposition. New Haven: Yale University Press.

Diamond, Larry. 1995. Promoting Democracy in the 1990s: Actors and Instruments, Issues and Imperatives. New York: Carnegie Corporation of New York.

$\longrightarrow$, Juan J. Linz, and Seymour Martin Lipset. 1989. Democracy in Developing Countries. Boulder, CO: Lynne Rienner.

Institute for the Study of Diplomacy. 1996. Pew Case Studies in International Affairs \& Institute for the Study of Diplomacy Books. Washington, DC: Edmund A. Walsh School of Foreign Service, Georgetown University.

John F. Kennedy School of Government. 1994. The Kennedy School Case Catalog. 4th ed. Cambridge, MA: Case Program, John F. Kennedy School of Government, Harvard University.

Lipset, Seymour Martin. 1981. Political Man: The Social Bases of Conflict. 2nd ed. Baltimore: The Johns Hopkins University Press.

O'Donnell, Guillermo, Philippe C. Schmitter, and Lawrence Whitehead, eds. 1986. Transitions from Authoritarian Rule: Tentative Conclusions About Uncertain Democracies. Baltimore: The Johns Hopkins University Press.

Quigley, Kevin F. F. 1997. For Democracy's Sake: Foundations and Democracy Assistance in Central Europe. Washington, DC: Woodrow Wilson Center Press.

_ 1996. Conversations on Democracy Assistance. Washington, DC: East European Studies, Woodrow Wilson Center.

The World Bank. 1996. EDI CASE Collection: Abstracts of Cases Available at EDI. 26 September Washington, DC: Economic Development Institute, The World Bank.

\footnotetext{
About the Author

Kevin F. F. Quigley is Vice President for Contemporary Affairs and Corporate Programs at the Asia Society. He has worked on democracy assistance programs in a variety of capacities, including Director of Public Policy at the Pew Charitable Trusts. He is the author of For Democracy's Sake: Foundations and Democracy Assistance in Central Europe.
} 